\title{
Physical characteristics and their influences on water dynamics in the Sefrou watershed, Northern Tabular Middle Atlas, Morocco
}

\author{
Youssef Hattafi ${ }^{1}$, Farah El Hassani ${ }^{2}$, and Abderrahim Lahrach ${ }^{1}$ \\ ${ }^{1}$ Universite Sidi Mohamed Ben Abdellah Faculte des Sciences et Techniques de Fes \\ ${ }^{2}$ Universite Euro-Mediterraneenne de Fes
}

June 17,2020

\begin{abstract}
The Sebou watershed is the main receiver of rainwater contributions in the North of Morocco. The present study is interested in the knowledge of the global Physical characteristics on water dynamics in the Sefrou watershed at the level of the Sefrou sub-watershed which belongs to this large hydrological unit and which occupies its south-western part. The approach followed in this study consisted initially, in acquiring the data, organizing it, and processing it by a geographic information system (GIS), in order to obtain a global idea on the distribution of the different parameters in the entourage concerned by this study. The application of geographic information system tools makes it possible to establish a set of maps that will help develop an excellent descriptive analysis characteristic of the watershed. In this paper, we present the analysis results of the geological, climatic and hydrological characteristics of an important area of the Middle Atlas, with the notable importance of precipitation, runoff and rivers for irrigation and the supply of drinking water. of cities in the region. The hydrological study of the Sefrou watershed has shown a typical Mediterranean regime, the watershed receives an average annual rainfall of $454.22 \mathrm{~mm}$, with a volume input of $183,96^{*} 10^{\wedge} 6{ }^{\wedge} 3$ /year and an average annual temperature of $16.62^{\circ} \mathrm{C}$. The actual evapotranspiration in the watershed is $389.22 \mathrm{~mm} /$ year which is $161,28.10^{\wedge} 6 \mathrm{~m}^{\wedge} 3 /$ year.
\end{abstract}

\section{Résumé}

Le bassin versant de Sefrou qui occupe la zone Sud-Est du plus grand bassin de Sebou, qui s'étend sur la partie septentrionale du Causse Moyen Atlasique. L'étude a été abordée par une caractérisation physiographique, morphologique de la zone étudiée, suivie par une synthèse hydrologique.

La démarche suivie dans cette étude consistait dans un premier temps, à acquérir les données, les organiser, et les traiter par un système d'informations géographique (SIG), afin d'obtenir une idée globale sur la répartition des différents paramètres dans l'entourage concerné par cette étude. L'application des outils de systèmes d'informations géographiques permet d'établir un ensemble des cartes qui vont aider à développer une excellente analyse descriptive caractéristique du bassin versant.

Dans cet article, nous présentons les résultats d'analyse des caractéristiques géologiques, climatiques et hydrologiques d'une zone importante du Moyen Atlas en apports pluviométriques et hydrologiques, du ruissellement et des rivières pour l'irrigation et l'approvisionnement en eau potable des villes de la région.

Le bassin reçoit une pluviométrie moyenne annuelle de 454,22 mm, avec un apport de volume de 183, 96 * $10{ }^{6} ?^{3}$ /an et une temperature moyenne annuelle de 16,62degC. L'evapotranspiration reelle dans le bassin versant est de $389,22 \mathrm{~mm} /$ an qui soient $161,28 \cdot 10^{6} \mathrm{~m}^{3} / \mathrm{an}$.

Mots cles : bassin versant de Sefrou, morphologie, hydrologie, Moyen Atlas, physiographie, Sebou . 


\section{Introduction}

Geographically, Morocco is situated in North Africa precisely with the African and the European plates which enforces a great richness, variety and complexity of Moroccan geology seeing its different structural domains.

The Middle Atlas region is characterized by its hugely diverse landscapes. As a matter of fact, its geological wealth is a considerable asset for the local development of the region. The quality of the geological outcrops makes it easy to read the history of this part of the Atlasic chain from the Paleozoic to the present day. The Middle Atlas, which constitutes an intracontinental chain whose mountainous and structural buildings are elongated essentially in the NE-SW direction, this chain is longitudinally subdivided into two structural domains separated by a major tectonic faults "NMAF", which separates the tabular Middle Atlas to the NW from the folded Middle Atlas to the SE. The Paleozoic outcrops there in several buttonholes like (Bsabis, El Menzel, Tazekka, Beni Mellala... ).

The Sefrou watershed in its downstream part, spreads over an area close to $405 \mathrm{~km} 2$ with a perimeter of $127.42 \mathrm{~km}$. The main watercourse originates from mountainous springs (Benima, J el Abed, Jbel l'Abd, Chaabat-Mbarek ...) and drains the Middle Atlas tabular area through the city of Sefrou towards its connection with the Oued Sebou which exists at the level of the Rif southern corridor crossing different geographical areas, and different bioclimatic environments.

Using a physical characterization method with a certain set of parameters allows us to follow and better understand the hydrodynamic behavior of the Watershed.

\section{Geographic and Geological settings}

\section{Geographic and geological aspects}

The Atlas system extends over some $2000 \mathrm{~km}$ between the Moroccan Atlantic margin in the West and Tunisia in the East. This system is bound by major lineaments, called South and North Atlas Faults, with adjacent subatlasic depressions and, is subdivided within Morocco in Middle and High Atlas (figure 1).

The Atlas Mountains represent an intracratonic belt and consist of Mesozoic and Cenozoic formations that accumulated in the foreland of the Tell-Rif Thrust Belt during the Alpine/Atlasic Orogeny.

The Middle Atlas is limited to the North by the Sais plain and the Rif front-thrust, to the NE by the Guercif Basin, to the $\mathrm{E}$ and the SE by the Moulouya depressions, and to the $\mathrm{W}$ by the Paleozoic massif of Central Morocco (belonging to the Western Moroccan Meseta). It is composed of the juxtaposition of two structural units: the tabular (or the "Middle Atlas Causse" ; Termier, 1936) and the folded Middle Atlas. These two units are separated by the North-Middle Atlas Fault as a major lineament. The tabular Middle Atlas is a sub-horizontal structure, composed mainly of neritic carbonates of the lower and middle Liassic. It is organized into a tiered plateau reflecting tilted block structures and consists of two sections (northern and southern), separated by the Tizi n'Tretten Fault. The folded Middle Atlas, oriented NE-SW, is composed of large syncline depressions delimited by narrow anticlinal ridges. the syncline depressions are occupied, essentially, by Toarcian and Dogger material. The Cretaceous and the Paleogene are confined to depressions situated to the $\mathrm{W}$ of the Boulemane meridian, while Neogene outcrops occur largely to the NE. Anticline ridges form. The hinge of narrow anticlines, generally represented by Liassic carbonates, is often affected by faults and injected with Triassic - Liassic shale and/or intruded by Jurassic/Cretaceous magmatites (Fedan \& El Hassani, 2018). 


\section{Geological description}

Reading the geological map of Sefrou 1: $100.000^{\text {th }}$ (Charrière 1989 : figure 2) and relative documents (i.e. Termier \& Dubar, 1940 ; Martin 1981 ; Benshili, 1987 ; Cirac, 1987 ; Charrière, 1984 and 1992 ; Fedan, 1988; Ahmamou 1987) allows us to subdivide the stratigraphic series of this part of the tabular Middle Atlas into four groups (figure 3):

A Paleozoic basement, with Ordovician to the Carboniferous series, in particular a complete Devonian sequences of conglomerates, limestones, reef limestones and carbonate marls (see Aboussalam et al., 2020).

Post-Paleozoic cover were sedimentation generally starts with the upper Triassic clay-evaporite series (gypsiferous argillites and mixed basalts);

- followed by Kandar Dolomitic Formation of Sebkha's environment (Charrière, 1992) of lower Liasic age dolomitic deposits. Then brecciated dolomites, dolomitic sands and bedded dolomites;

- The Liasic series continues with massive limestones with Oncolites, Gastropods, Terebratula and imperforate foraminifera, locally dolomitized;

- Flint-bedded limestones with ammonites (Tropidoceras) at the base, which is overcome by reef constructions (lumachel limestones and epi-reef levels);

- Ammonite limestone (protogrammoceras celebratum and Fuciniceras);

- And finally, oolite limestones with reefs which shows frequent dolomitization.

After a major unconformity, above the Jurassic series, outcrop north of Sefrou (in the Sais plain and its borders) marly formations that filling the basin (fig. 3) that shows from base to top:

- Red formations with volcano-sedimentary levels and volcanic flows (in the area of Zra wadi), then a formation composed of clays, marls and lacustrine limestones; channeled sandstones and conglomerates (fluvio-deltaic facies); finally rose marl showing silt-sandstone intercalations with microfauna.

- The three Messinian formations:

- Bhalil Formation (biocalcarenites, reef constructions and conglomerates);

- Sefrou Formation of ocher silts with Globorotalia dutertrei;

- and finally, the Fez "blue marls" Formation which is rich in planktonic foraminifera.

The stratigraphic series close, after an unconformity, by lacustrine limestones of the Sais (middle to upper Pliocene) and finally the Quaternary Formations (travertines, crusts, alluviums, glacis and terraces).

\section{Climate context of the watershed}

\section{Annual precipitation}

Precipitation decreases towards the SE where the station of Anoceur is located. It has an average of $504 \mathrm{~mm}$, lower than that of Sefrou $(517.2 \mathrm{~mm})$, and that of Allal El Fassi dam $(335.3 \mathrm{~mm})$. This can be explained by the orographic effect of the sequences of high ridges. The annual average is $361 \mathrm{~mm}$ in Azzaba, $396.2 \mathrm{~mm}$ in Fez, $407.4 \mathrm{~mm}$ in Ain Timedrine. Thus, from the results obtained for the 5 stations, it can be deduced that the average rainfall for the sector studied is $417.8 \mathrm{~mm}$, for the period between 1957/58 and 2009/10.

\section{Average monthly precipitation}

In the Sefrou watershed, there was a maximum average monthly rain (figure 4) of $54.92 \mathrm{~mm}$ in December, which makes this month the wettest of all the stations, while July is the driest. with an average rain of 3.86 $\mathrm{mm}$, this will directly influence the runoff flows. 


\section{Assessment of the blade of water fallen on the watershed}

The fallen layer of water can be estimated by several methods, making it possible to integrate into point data relating to the different stations, a surface result, which makes it possible to estimate spatial precipitation. 'Thiessen polygon' is the applied methodology, as a statistical method, which amounts to carrying out the weighted average of the precipitation measured in the rainfall stations of the watershed. The influence area of each station measurement "called the Thiessen polygon" is the weighting factor. These polygons are obtained graphically (figure 5), by plotting the perpendicular bisectors of the segments connecting two neighboring rainfall stations, on a geographic or topographic map.

\section{Isohyet method}

To make interpretation of precipitation easier, the map of isohyets shows that there is a progressive precipitation gradient between the different stations. From this figure, we notice that the rainfall gradient increases from North to South in the direction of high altitudes (figure 6).

Thus, precipitation becomes significant at the stations located at high altitudes. We note that some summer months are characterized by the predominance of rain mainly linked to the frequency of local thunderstorms. These are due to the strong insolation on the ground which sometimes gives rise to updrafts which causes the formation of stormy precipitation.

\section{Estimated mean of the water slide calculated by the three methods}

In order to reconcile between the three different values found by each method (table 1), and to quantify the volume of the blade of water fallen on the basin, it is recommended to calculate an average between them. Annual volume of precipitated water (in $\mathrm{m}^{3}$ ), for the Sefrou watershed, can be estimated as follows:

$\mathrm{V}=183,96.10^{6} \mathrm{~m}^{3} /$ year

\section{Evaporation, Evapotranspiration and flow deficit}

\section{Real Evapotranspiration (ETR)}

Actual evapotranspiration (ETR) is the sum of the quantities of water evaporated by the soil and by plants when the soil is at its current specific humidity and the plants at a stage of real physiological and sanitary development under real conditions and taking into account the water available.

It turns out that the actual evapotranspiration is very important, it is calculated from the average of the three methods (Thornthwaite, 1948; Coutagne,1954; Turc, 1955) is $389.22 \mathrm{~mm}$ for the entire watershed, whose annual average precipitation represents a value of $454.22 \mathrm{~mm}$. The percentage of loss represents $85.69 \%$ of inflows from the water system having a volume close to 161.28 million $\mathrm{m}^{3}$, while the rest will represent the volume of water drained and the amount of underground infiltration, the latter reaching $14,31 \%$ with a value of 22.68 million $\mathrm{m}^{3}$ /year.

\section{Physiographic Characteristics of Sefrou watershed}

The study area is located in the Sefrou watershed between the parallels $\left(33.41^{\circ} \mathrm{N} ; 34^{\circ} \mathrm{N}\right)$ and the meridians $\left(4.43^{\circ} \mathrm{W} ; 4.56^{\circ} \mathrm{W}\right)$. It is limited to the North by the Allal El Fassi dam and to the South (upstream part) by Chaabat Mbark and Jbel Beima. 


\section{Morphometric Characteristics}

According to digitalization, the Sefrou watershed covers an area of $405 \mathrm{Km}^{2}$ and a perimeter of $127.42 \mathrm{Km}$. These are small sizes that make it vulnerable to any rainfall.

\section{Shape characteristic}

The shape of the hydrograph at the outlet of the watershed depends on the shape of the latter. There are, thus, different morphological indices which allow to characterize the environment, but also to compare different basins.

\section{Compactness Index of Gravelius}

The Compactness Index $\mathrm{K}_{\mathrm{G}}$ of Gravelius (1914), defined as the ratio of the perimeter of the watershed to the perimeter of the circle having the same area:

Where: $K G=\frac{P}{2 \sqrt{\pi} \cdot \mathrm{A}} \approx 0.28 \cdot \frac{P}{\sqrt{ } A}$

- $\mathrm{K}_{\mathrm{G}}$ is the index of compactness of Gravelius,

- A: surface area of the catchment area $\left[\mathrm{km}^{2}\right]$,

- P: watershed perimeter $[\mathrm{km}]$.

In our case: $\mathrm{K}_{\mathrm{G}}=1,77$

From the value of $\mathrm{K}_{\mathrm{G}}$ it can be concluded that the watershed is elongated with probable linear erosion, this favors, for the same rainfall, low peak flood flows due to the delay of water delivery to the outlet.

\section{Horton Compactness Index}

The Horton Compactness Index (Horton, 1932) is calculated as the ratio of the average width $l m$ to the length of the mainstream $\mathrm{L}$ by the following relationship:

$\mathrm{Kh}==\frac{\operatorname{lm}}{L}$

With:

- $\operatorname{lm}$ : the average width of the watershed $(\mathrm{km})$.

- $L$ : the length of the main watercourse $(\mathrm{km})$.

In our catchment area: $l m=13.56 \mathrm{~km}$ and $L=45.76 \mathrm{~km}$

$\mathrm{Kh}=0.0065 \mathrm{Km}^{(-1)}$

As the Kh value is very low this confirms that the watershed is elongated.

\section{Shape Coefficient}

It is the ratio between the average width $(\mathrm{lm})$ and the axial length at watershed level (La).

$\mathrm{Kf}=\frac{\mathrm{lm}}{\mathrm{La}}$

With:

- $\mathrm{lm}$ : the average width of the watershed $(\mathrm{km})$;

- La: axial length $(\mathrm{km})$.

At the level of our watershed, we have: $1 \mathrm{~m}=13.56 \mathrm{~km}$ and $\mathrm{L}=29.76 \mathrm{~km}^{2}$.

$\mathrm{K}_{\mathrm{f}}=0.45$

This implies an elongated shape of the catchment area. 


\section{Coefficient of elongation of Shumm (E) (Shumm, 1956)}

It is calculated from the ratio of the diameter of a circle having the same area as the catchment area to the maximum length of the catchment area:

$\mathrm{E}=\frac{\sqrt[2]{A / \pi}}{\operatorname{Lmx}}$

With: $\operatorname{Lmx}=\sum_{1}^{4} \frac{\mathrm{Lm}}{n} \sum_{1}^{4} \frac{\mathrm{Lm}}{n}$

- A: Area of the watershed in $\mathrm{km}^{2}, \mathrm{~A}=405 \mathrm{~km}^{2}$;

- $\mathrm{n}$ : number of order $=4$;

- Lmx: maximum length of watercourses in the watershed $\operatorname{Lmx}=74.55$;

- lm: average length of rivers.

$l m=298,207 \mathrm{~km}$, So: $\mathrm{E}=0,16$

The E coefficient shows a relatively low value, which may mean that the watershed has not yet reached a mature phase in old age.

\section{The equivalent rectangle}

The concept of the equivalent rectangle was first introduced by Roche (1963), its interest is to compare the influence of watershed characteristics on flow. This notion assimilates the watershed to a rectangle with the same perimeter and surface area, the same compactness index, and therefore the same hypsometric distribution. In this case, the contours become parallel to the side of the equivalent rectangle. Climatology, soil distribution, vegetation cover and drainage density remain unchanged between contours. The longer the equivalent rectangle is elongated, the less it will drain. The dimensions of the equivalent rectangle are determined by the following formula:

$L=\frac{\mathrm{Kg} \sqrt{A}}{1,12} *\left(1+\sqrt{1-\left(\frac{1,12}{\mathrm{Kg}}\right)^{2}}\right)$ with $\mathrm{l}=\frac{\mathrm{Kg} \sqrt{A}}{1,12} *\left(1-\sqrt{1-\left(\frac{1,12}{\mathrm{Kg}}\right)^{2}}\right)$

With:

- Kg: Gravelius index of compactness.

- S: catchment area $(\mathrm{Km})$;

- L: length of the equivalent rectangle (Km);

- l: width of the equivalent rectangle (Km);

- For our pool we have the following characteristics.

$\mathrm{L}=56,43 \mathrm{~km}$ and $\mathrm{l}=7,18 \mathrm{~km}$

The values of the dimensions (figure 7 ) of the watershed allow us to deduce that we have a relatively elongated watershed.

\section{Trihedral representation}

The trihedral representation is a model of representation developed for the first time by P.Verdeil (1988), it corresponds to the sum of two right-angled triangles whose side of the corner line must be designated by $\mathrm{L}$ which constitutes an adjacent side and represents the main watercourse and therefore the watershed line between the two banks of the watershed.

For this purpose, it is assumed that each bank of the main watercourse is assimilated by a triangle of the same area as the bank.

For the right bank:

Calculation of the angle $\alpha 1=\operatorname{Arctg}\left(\frac{2 A i}{L^{2}}\right)$

With: 
- A: the area of the right bank; $\mathrm{A}=224,033 \mathrm{~km}^{2}$;

- L: the length of the main watercourse; $\mathrm{L}=45.76 \mathrm{~km}^{2}$.

$\alpha 1$ : the angle of the right bank triangle

$\alpha 1=12.077^{\circ}$.

For the left bank:

Calculation of the angle $\alpha 2=\operatorname{Arctg}\left(\frac{2 A i}{L^{2}}\right)$

With:

- A: the area of the left bank; $\mathrm{A}=180,97 \mathrm{~km}^{2}$;

- L: the length of the main watercourse; $\mathrm{L}=45.76 \mathrm{~km}^{2}$.

$\alpha 1$ : the angle of the right bank triangle

$\alpha 2=9.81^{\circ}$

According to the trihedral representation of the watershed(figure 8), we can see that the two banks are relatively asymmetrical compared to the main river, the right bank is more developed than the left bank, which can lead us to believe that the drainage is distributed heterogeneously on both sides of the Sefrou watershed.

\section{Altitude Characteristics}

\section{Hypsometric Map}

The relief of the watershed is characterized by a hypsometric map and curve. The study of the relief characteristics allows to determine the morphology of the watershed, its interactions with meteorological phenomena and its hydrological behavior, and as the relief directly influences all hydro-climatic factors (precipitation, temperatures, vegetation, flow ....). The Hypsometric map is obtained by delimiting altitude ranges of the watershed by $200 \mathrm{~m}$ equidistance level curves. According to this map below (figure 9), we can see that the high altitudes are located towards the southern part of the watershed within the "Causse Moyen Atlas" ( $>$ $1500 \mathrm{~m})$, however further north towards the downstream part $(<300 \mathrm{~m})$.

\section{Hypsometric curve}

To understand the variations in altitudes within the Sefrou watershed (figure 10), we determined a hypsometric curve which allowed us to translate the distribution of altitudes within the study area and allows to determine the characteristic altitudes.

From this curve, it can be concluded that the altitude varies enormously despite the relatively small area of the watershed and the area is small in relation to the change in altitude, characterizing a steep watershed. The characteristic altitudes of the watershed: average altitude, median altitude...

the average altitude is calculated according to the following formula:

$\mathrm{Hm}=\sum_{1}^{i} \frac{\text { Aihi }}{A}$

With:

- Ai: this is the area between two contour lines $\left(\mathrm{Km}^{2}\right)$

- hi: Average altitude between two contour lines (m)

- A: Total area of the watershed $\left(\mathrm{km}^{2}\right)$

For the Sefrou watershed, the average altitude is: $\mathrm{Hm}=928.36 \mathrm{~m}$ 
Note that this is almost equal to the same value given by the ArcGis according to a classification of the DTM: $926.52 \mathrm{~m}$.

The median altitude is the value read at $50 \%$ of the total surface of the watershed on the hypsometric curve: Hmed $=905 \mathrm{~m}$

\section{Concentration time}

Defined as the time after which the particle of water falling in the area furthest from the outlet will reach it. The concentration-time is a characteristic of the watershed which essentially depends on the surface of the basin, the lithology, the rainfall, slopes, the length, and the density of the hydrographic network. For its calculation, there are several formulas. Some are in common use in Morocco. Using the Giandotti formula (Giandotti M. 1937) we will quote:

$\mathrm{Tc}=\frac{4 * \sqrt{A}+1,5 L}{0,8 \sqrt{\mathrm{Hmoy}}}$

With:

- Tc concentration time (hours);

- A: area of the watershed in $\mathrm{km}^{2} ; \mathrm{A}=405 \mathrm{~km}^{2}$;

- The length of the main Thalweg watercourse in $(\mathrm{km}) ; \mathrm{L}=45.68 \mathrm{~km}$.

- Hm: average altitude $(\mathrm{m}) ; \mathrm{Hm}=928.36 \mathrm{~m}$.

For our watershed: $\mathrm{Tc}=6 \mathrm{~h} 11 \mathrm{~min}$

Based on the value of the concentration time at the Sefrou watershed, which makes it possible to classify the watershed among the watersheds that have a relatively short concentration time.

\section{Slope study}

Our objective is to study the slope's indices and characteristics to define their classification because the slope plays an important role in the hydrological characterization of the watershed in order to establish the hydrological balance. It directly influences the infiltration and runoff for the same downpour and with the same permeability. In the Sefrou watershed the following map is obtained ( figure 11):

At the level of the slope map, we can notice an abundance of moderate slope values whose average value is $19 \%$. The degree of slope increases rapidly at the level of major faults and which can reach values more than $40 \%$.

\section{The overall slope indexes}

The global slope index Ig makes it possible to assess the importance of the relief on the basin. It is defined as the ratio between the useful drop $(\mathrm{Du})$ and the length $(\mathrm{L})$ of the equivalent rectangle. This Ig index characterizes the relief of the pelvis. It is given by the following formula:

$\mathrm{Ig}=\frac{\mathrm{Du}}{\mathrm{Leq}}=\frac{H 5 \%-H 95 \%}{\mathrm{Leq}}$

With Ig: overall slope index in $\mathrm{m} / \mathrm{km}$

- $\mathrm{H} 5 \%$ the altitude which corresponds to $5 \%$ of cumulative surface

- $\mathrm{H} 95 \%$ the altitude which corresponds to $95 \%$ of cumulative surface

- From: Height difference H5\% - H95\%, Du = 1080m

- L: equivalent rectangle length in $(\mathrm{km}), \mathrm{L}=56.43 \mathrm{~km}$

- $\mathrm{Ig}=20 \mathrm{~m} / \mathrm{km}$

- $\operatorname{Ig}=0.02$

According to the table of Ostrom the value of Ig allows us to deduce that the relief of the watershed is quite strong. 


\section{Specific drop Ds}

The specific elevation considers the area of the watershed and the global slope index Ig. This index allows us to compare the basins with each other and is defined by the following formula:

$\operatorname{Ds}=\operatorname{Ig} \sqrt{A}$

With:

- Ig: global slope index $\mathrm{Ig}=20 \mathrm{~m} / \mathrm{km}$

- A: area in $\mathrm{km}^{2} \mathrm{~A}=405 \mathrm{~km}^{2}$

Ds $=402.24 \mathrm{~m}$

According to the classification of the Ostrom (table 2), the value of Ds at the level of the catchment area shows a relief which is relatively strong.

\section{Characteristics of the hydrological network}

The hydrographic network designates a hierarchical and structured set of channels that provide surface drainage, permanent or temporary, of a watershed or a given region. The hierarchy of the hydrographic network is manifested by the increasing importance of its elements, from the original ramifications of the upstream devoid of tributaries (called order 1 in the classification of Horton - Strahler, 1952), to the main collector. The order number of this one increases (order 2 , orders $3,4,5$, etc.) with the size of the basin, the number of tributaries, and the density of the drainage.

The density of the river system increases when the climate is wetter, the steeper slopes, the rocks or surface formations less permeable.

At the level of our watershed (figure 12), the main river stretches $45.68 \mathrm{~km}$ from upstream and high altitudes towards the outlet. According to the ArcHydro function at ArcGis, we were able to calculate the length of the main watercourse and even for thalwegs of small extension with a flow direction of the Sefrou watersheds from South to North.

\section{Drainage density}

Each hydrographic network is characterized by a drainage density, which is defined as the ratio between the sum of the lengths of the current lines for a hydrographic network over the area of the watershed. It is given by the following formula:

$\mathrm{Dd}=\frac{\sum L i}{A}$

With:

- Li: Accumulated length of thalwegs (permanent and temporary) in Km.

- A: Area of the watershed in $\mathrm{km}^{2}$.

For the Sefrou watershed: [?] $\mathrm{Li}=298.207 \mathrm{~km}$ and $\mathrm{A}=405 \mathrm{~km} 2$.

Hence Dd $=0.73 \mathrm{~km}^{-1}$

This value gives us an idea that the hydrographic network of the watershed is dense.

\section{Torrentiality coefficient}

This coefficient considers the frequency of elementary thalwegs (of low order, generally of order 1) by the density of drainage, the value is given by the following relation:

$\mathrm{Ct}=$ Dd.F1 
With:

- Dd: drainage density, $\mathrm{Dd}=0.73 \mathrm{~km}^{-1}$

- F1: designates the frequency of elementary thalwegs $\mathrm{F} 1=\mathrm{N} 1 / \mathrm{A} ; \mathrm{F} 1=0.21$

- N1: number of streams of order 1.

$\mathrm{Ct}=0.16$

The value is relatively low since the torrentiality coefficient depends directly on the concentration time (Tc $=6 \mathrm{~h} 11 \mathrm{~min})$, (this value is related to the nature of the relief, slope, area of the basin, precipitation, etc.)

\section{Hierarchy of the network}

As the ramification of the network is complex, we proceed by a classification on the set of ramifications of the network. In the Strahler classification, any drain which has no tributary is assigned the value 1. Then, the calculation of the value of each drain is done according to the following method: a drain of order $n+$ 1 is derived of the confluence of two drains of order n. The Strahler order of a watershed is the order from the main drain to the outlet. Improvements have been made to this method by Scheidegger (1966) and developed by Schriver-Mazzuoli (2012) and to match the Strehler order with the importance of the flow on the main drain. The map (figure 13) clearly shows that the total order of the Sefrou watershed is 4 which implies a fairly developed and branched flow network. (Strehler, 1952).

\section{Longitudinal profile of the watershed}

The use of the profile along the main river (figure 14) allows us to estimate the average slope and then we can calculate the characteristic Tc. We note that there are several slope breaks indicating erosion at the level of the breaking section. These ruptures are generally due to changes in facies. The main tributaries occupy the right bank with an appreciable density.

\section{Conclusion}

The different physiographic characteristics (table 3) of the Sefrou watershed are summarized in the table below. The parameters characterizing the relief show an elongated catchment area. As L is relatively small, the Tc value for a characteristic downpour is relatively average. The hypsometric curve shows a relief which decreases as it moves towards the outlet of the pelvis (northern part of the study area). Relatively average altitudes (500 to $900 \mathrm{~m}$ ) are the most frequented.

The hydrographic network is relatively denser at the level of the right bank than on the left bank, the two banks remain almost symmetrical according to their surfaces and the trihedral representation.

\section{Hydrological characterization}

\section{Data collection}

The available mean annual flows are those of the Ain Louali station (figure 15), with the following geographical coordinates $(\mathrm{X}=555,650 \mathrm{~m} ; \mathrm{Y}=377,000 \mathrm{~m} ; \mathrm{Z}=245 \mathrm{~m})$, located downstream of the catchment area towards the outlet, these data were obtained on the basis of the monthly values of the flows provided by the Sebou Hydraulic Watershed Agency. The period runs from 1968 to 1970 and from 1979 to 2005, a period of 29 years.

It should be noted that the converting data for the 1970/79 period are absent, to resolve this problem and to ensure data continuity, the values for these nine years have been estimated, following the shape of the flow curve by statistical correlation methods. 


\section{Study of the flow rate}

\section{Average annual flow}

The series of observations thus taken shows that the average annual flow is around $454 \mathrm{l} / \mathrm{s}$. The following figure shows the evolution of annual flows during the period considered(figure 16):

The specific flow or Qsp is a measure of the average flow of precipitation within a river catchment area. It is defined as the number of liters of water that flows on average every second per square kilometer of the basin. Formulation: this is the value of the flow $\mathrm{Q}\left(\mathrm{L} / \mathrm{s} \mathrm{or} \mathrm{m}^{3} / \mathrm{s}\right)$ relative to the surface A of the watershed $\left(\mathrm{km}^{2}\right)$ :

$\mathrm{Qsp}=\mathrm{Q} / \mathrm{A}$

The specific flow is also used to express peak flows during floods. In general, the peak Qsp during floods decreases when the size of the watershed increases.

Specific flow : Qsp $=1.12 \mathrm{l} / \mathrm{s} / \mathrm{km}^{2}$

The highest average interannual flow is $1000 \mathrm{l} / \mathrm{s}$ recorded in 1969/1970, while the lowest is $300 \mathrm{l} / \mathrm{s}$ recorded in 1993/1994 and in 2002/2003.

\section{Average monthly flows}

The maximum monthly average flow appears in March $(390 \mathrm{l} / \mathrm{s})$, on the other hand the minimum flow is observed in August (325 l/s), the following hydrogram shows the variation of the average monthly flows in Ain Louali (figure 17):

This figure shows that the water concentration requires seven months, from September to March to reach its maximum which represents the peak in March with a value of $390 \mathrm{l} / \mathrm{s}$. The time of the recession begins from the end of March to August, a period of five months to arrive at the minimum quantity of flows. It should be noted that the flood and recession times are approximate since we work with average monthly flows.

\section{Specific flows and height of the flow of water}

Many hydrological studies often focus on comparing the hydrological regimes of different stations or streams. It is therefore advantageous to give here the specific flows in l/s/Km2 for the period from 68/69 to 2003/04. The specific flow formula:

$\mathrm{q}=\mathrm{Q} / \mathrm{S}$

- q: specific flow in $\mathrm{l} / \mathrm{s} / \mathrm{Km} 2$.

- Q: average flow in $1 / \mathrm{s}$.

- S: area of the catchment area in $\mathrm{Km} 2$.

The height of the flow of water in $\mathrm{mm}$ is given as a function of $\mathrm{q}$ which is the specific flow rate (Parade, 1974):

- $\mathrm{H}=31.536 \times \mathrm{x}$ for one year.

- $\mathrm{H}=2,419 \times \mathrm{q}$ for a month of 28 days.

- $\mathrm{H}=2,592 \times \mathrm{q}$ for a month of 30 days.

- $\mathrm{H}=2,678 \times \mathrm{q}$ for a month of 31 days.

The monthly values of the specific flow rate and the height of the flow of water flow are given in the following table (table 4):

The total volume of water flown is $27.73 \mathrm{~mm} /$ year, or approximately $6 \%$ of the average volume of water that fell into the watershed $(454.22 \mathrm{~mm} /$ year $)$. The H/P runoff coefficient $(27.73 / 454.22)$ is 0.061 . 


\section{Rainfall-discharge relationship}

The following table (table 5) shows the monthly flows and precipitation for the period 68/69 to 2004/2005:

When we compare the hydrograph of average monthly flows with that of average monthly precipitation (figure 18), we see that there is a synchronism between flows and monthly precipitation. Indeed, the two curves thus plotted for the same period roughly evolve in the same meaning and in the same way:

- The decrease in rainfall inputs is accompanied by a late decrease inflow recorded around the summer months.

- These are maximum precipitation values in December and January followed by a maximum flow in March, with a delay of one month; time required for the arrival of significant inputs to the measurement station which is located near the outlet of the watershed. This discrepancy can be explained by the lithological nature of the watershed or by its morphology.

In general, the flow of runoff is one of the most important components of the outflow from a hydrological regime fed by precipitation.

\section{Final water balance estimate}

The main purpose of any hydrological study is to estimate the water balance of the region concerned, to establish a database corresponding to local water reserves, as well as to guarantee integrated management of these resources. The following table summarizes the results of the Sefrou watershed water balance assessment (table 6):

According to the table (6), the maximum percentage is that of evapotranspiration (87.67\%), which can be explained by the high-temperature values during the dry period and by the evolution of the vegetation in the area.

It is important to underline the fundamental points concerning the study carried out under this paragraph. The aspects relating to the hydrology of the Sefrou catchment area bear witness to the Mediterranean hydrological character where the dry season is strongly pronounced. It is therefore obvious to deduce that the hydrological drought has been well marked during the previous 30 years, which has, moreover, been confirmed by the method of differences in the average interannual flow rates.

The study of the hydrological regime using the method of determining the "precipitation-flow" relationship has made it possible to define a rainfall regime. The mean annual flow is $454 \mathrm{l} / \mathrm{s}$.

The study of the monthly flows shows that there is a similar evolution with a small delay between the maximum values of the flows and the monthly flow coefficients show that the Sefrou catchment area is characterized by an irregular regime. For its part, the study of the specific flows and the height of the runoff water level made it possible to estimate the runoff coefficient which is 0.061 .

The water balance showed that the runoff estimation represents $6.06 \%$ of total precipitation. As for infiltration, it represents $6.23 \%$ of precipitation.

Sefrou watershed provides real water resources and thus ensures the supply of drinking water for the inhabitants of the Middle Atlas regions and more specifically for the habitats of the city of Sefrou. Despite the usefulness of these important capacities, they were causing risks represented by winter floods causing human and material damage, which is solved by the establishment of development projects in the region.

\section{Conclusion}

The Sefrou watershed occupies the SW part of the Sebou watershed. It is extended over a total area, up to the intersection with the famous Oued Sebou, of $404.89 \mathrm{Km} 2$ with a perimeter of $127.42 \mathrm{Km}$; that is $1 \%$ of the Sebou watershed. 
The morphometric parameters show that the Sefrou watershed is elongated $(\mathrm{L}=56.43 \mathrm{Km}$ and $\mathrm{l}=7.18 \mathrm{Km})$. The hypsometry is characterized by altitudes that progressively decrease from the South to the northern part of the basin. According to the hypsometric curve, the altitudes between $500 \mathrm{~m}$ and $900 \mathrm{~m}$ occupy most of the surface of the basin. The relief is relatively strong according to the global slope index and the specific gradient. The hydrographic network is very important on the eastern bank than on the western bank, and this is related to the lithology and the vegetation cover.

In spite of the diversity of the lithological formations that outcrop in the Sefrou catchment area, they can be grouped into two large units the southern sector (the Middle Atlas "cause") which is characterized by essentially carbonate formations constituting a highly developed karstic system thus conditioning a high permeability in this part of the catchment area.

The rainfall collected in the stations during 1970/2011 is characterized by fluctuations between the different stations and hydrological cycles. The mean annual and monthly precipitation is

\section{References}

Aboussalam Z.S., Becker R.T., Richter J., Hartenfels S., El Hassani A., \& Eichholt S. (2020) : The unique Devonian of Immouzer-du-Kandar (Middle Atlas basement) - biostratigraphy, faunas, and facies development. Frontiers in Science and Engineering, Scientific Journal of Hassan II Academy of Science and Technology. Vol. 10 Ndeg1 pp : 127-175.

Ahmamou M. (1987) : Etude sedimentologique des calcaires lacustres saissiens (Plio-Quaternaire) du bassin de Fes-Meknes (Maroc). These 3e cycle, Univ. Aix-Marseille III ; 175 p.

Benshili K. (1989): Lias-Dogger du Moyen Atlas plisse (Maroc). Sedimentologie, biostratigraphie et evolution paleogeographique. - Documents des Laboratoires de Geologie de Lyon, 106: 285 p.

Charrière A. (1989) : Carte géologique du Maroc, feuille de Sefrou au 1:100.000ème. Notes \& Mém. Serv. Géol. Maroc, №354.

Charrière A. (1992) : Evolution paléogéographique méso-cénozoique du Moyen Atlas (Maroc) en relation avec les domaines atlantique et méditerranéen. Notes \& Mém. Serv. geol. Maroc, nº 366, pp. 189-203.

Charrière A., (1984) : Evolution néogène de bassins continentaux et marins dans le Moyen Atlas central (Maroc). BuU. Soc. geol. Fr. (T), XXVI, 6, pp. 1127-1136.

Cirac P. (1987) : Le bassin sud-rifain occidental au Néogène supérieur. Evolution de la dynamique sédimentaire et de la paléogéographie au cours d'une phase de comblement. - Mem. Inst. geol. Bassin d'Aquitaine, Bordeaux n ${ }^{\circ}$ 27, 287 p.

Coutagne, A. (1954). Quelques considérations sur le pouvoir évaporant de l'atmosphere, le déficit d'écoulement effectif et le déficit d'écoulement maximum. La Houille Blanche, 360-369.

Fedan B. \& El Hassani A. (2018) : The Jurassic of the Atlas Domain (Morocco). Field Guidebook 10th International Symposium "Cephalopods - Present and Past" . Munster. Forsch. Geol. Palaont. , 110 ; pp : 119-144.

Fedan B. (1988) : Evolution géodynamique d'un bassin intraplaque sur décrochements : le Moyen Atlas (Maroc) durant le Meso- cénozoïque. Thèse Sciences, Univ. Mohammed V de Rabat, 338 p.

Giandotti M. (1937) : Idrologia. Barbera Ed., Firenze, 107 p.

Gravelius H. (1914) Grundriss der gesamten Gewässerkunde, Band 1: Fluss künde (Compendium of Hydrology, vol. 1: Rivers, in German, pp: 265-278). Göschen, Berlin, Germany. 
Horton R.E. (1932) : Drainage basin characteristics. Transactions, American Geophysical Union 13, pp: $350-361$.

Horton, R. E. (1945) : Erosional development of streams and their drainage basins: hydro-physical approach to tquantitative morphology. Geol. Soc. America Bull., 56, pp. 275-370.

Martin J. 1981. Le Moyen Atlas central, étude géomorphologique.Notes \& Mém. Serv. géol. Maroc, 258.

Roche E. (1963) : Hydrologie de surface, Ed. Gauthier-Villars, Paris 430 p. 204 fig.

Scheidegger, A. E. (1966) : Stochastic branching processes and the law of stream orders", Water Resources Researches, vol. 2, n 2, 199-203.

Schriver-Mazzuoli, L. (2012) : La gestion durable de l'eau : Ressources - Qualité - Organisation, Dunod, 2012, 250 p. (ISBN 978-2-10-058050-7 et 2-10-058050-7, lire en ligne [archive]), p. 6

Schumm, S.A. (1956). Evolution of drainage systems and slopes in badlands at Perth Amboy, New Jersey. Geological Society of America Bulletin, 67, 597-646.

Strahler, A. N. (1952) : Hypsometric (area-altitude) analysis of erosional topology", Geological Society of America Bulletin 63 (11), pp :1117-1142.

Termier H. \& Dubar G. (1940) : Notice explicative de la carte géologique provisoire du Moyen Atlas septentrional au 1/200 000. - Notes et M. Serv. geol. Maroc, 24 bis, 74 p.

Termier H. (1936) : Études géologiques sur le Maroc central et le Moyen-Atlas septentrional. Notes et Mém. Service des Mines et de la Carte géologique du Maroc, N³3, 3 tomes,1566 p.

Thiessen A.H., (1911): Precipitation showers Foe-large areas. Monthly weather Rev, p182.

Thornthwaite C.W., (1948) : An approach toward a rational classification of climate. George Review.).

Thornwaite, C. W., 1948: An approach towards a rational classification of climate. Geogr. Rev., 38, 55-89.

Turc, L., 1955: Le bilan de l'aue des sols. Relations entre les precipitations, l'evaporation et l'ecoulement, INRA, Paris, 252 pp.

VERDEIL P. (1988) : Abaque de calcul de l'ETR (Régions semi-arides), 01 abaque.

\section{Hosted file}

figure.docx available at https://authorea.com/users/334365/articles/460356-physicalcharacteristics-and-their-influences-on-water-dynamics-in-the-sefrou-watershed-northerntabular-middle-atlas-morocco

\section{Hosted file}

table.docx available at https://authorea.com/users/334365/articles/460356-physicalcharacteristics-and-their-influences-on-water-dynamics-in-the-sefrou-watershed-northerntabular-middle-atlas-morocco 